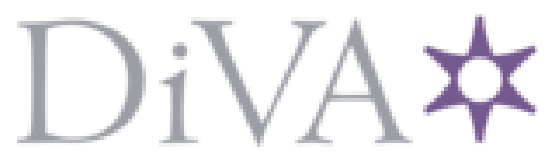

http://www.diva-portal.org

This is the published version of a paper published in The Journal of Aesthetic Education.

Citation for the original published paper (version of record):

Viktor, J. (2014)

Perfectionist Philosophy as a (an Untaken) Way of Life.

The Journal of Aesthetic Education, 48(3): 58-72

Access to the published version may require subscription.

N.B. When citing this work, cite the original published paper.

Permanent link to this version:

http://urn.kb.se/resolve?urn=urn:nbn:se:du-19233 


\section{Perfectionist Philosophy as a (an Untaken) Way of Life}

\section{VIKTOR JOHANSSON}

\section{Introduction}

I am honored to respond to Paul Guyer's elaboration on the role of examples of perfectionism in Cavell's and Kant's philosophies. Guyer's appeal to Kant's notion of freedom opens the way for suggestive readings of Cavell's work on moral perfectionism but also, as I will show, for controversy.

There are salient aspects of both Kant's and Cavell's philosophy that are crucial to understanding perfectionism and, let me call it, perfectionist education, that I wish to emphasize in response to Guyer. In responding to Guyer's text, I shall do three things. First, I shall explain why I think it is misleading to speak of Cavell's view that moral perfectionism is involved in a struggle to make oneself intelligible to oneself and others in terms of necessary and sufficient conditions for moral perfection. Rather, I will suggest that the constant work on oneself that is at the core of Cavell's moral perfectionism is a constant work for intelligibility. Second, I shall recall a feature of Cavell's perfectionism that Guyer does not explicitly speak of: the idea that perfectionism is a theme, "outlook or dimension of thought embodied and developed in a set of texts." Or, as Cavell goes on to say, "there is a place in mind where good books are in conversation. ... [W] [Wat they often talk about ... is how they can be, or sound, so much better than the people that compose them." ${ }^{1}$ This involves what I would call a perfectionist conception of the history of philosophy and the kinds of texts we take to belong to such

Viktor Johansson is a lecturer at the Department of Child and Youth Studies, Stockholm University. He has published several articles within philosophy of education in journals such as Educational Theory (2010), Journal of Philosophy of Education (2011), and Journal of Aesthetic Education (2013). He recently finished his doctoral thesis, "Dissonant Voices: Philosophy, Children's Literature, and Perfectionist Education" (2013). Most of his work draws on Stanley Cavell and Ludwig Wittgenstein and ranges from issues of marginalization, education, language learning, and the philosophy of literature and aesthetics, in particular in relation to children's literature. 
history. Third, I shall sketch out how the struggle for intelligibility and a perfectionist view of engagement with texts and philosophy can lead to a view of philosophy as a form of education in itself.

In concluding these three "criticisms," I reach a position that I think is quite close to Guyer's, but with a slightly shifted emphasis on what it means to read Kant and Cavell from a perfectionist point of view.

\section{Perfectionism and Intelligibility}

In "Examples of Perfectionism," the leading essay in this issue, Guyer rightly identifies making oneself intelligible to be at the heart of moral perfectionism. He also underlines Cavell's saying that moral perfectionism is not to be understood as an alternative to other positions in ethics. However, Guyer then goes on to add that the reason perfectionism cannot be an alternative to other ethical positions is that making oneself intelligible "presupposes some additional goal beyond intelligibility as such: to understand our actions and to justify them ... we have to understand what they are aimed at" ("Examples of Perfectionism," 7). It would seem then that moral perfectionism, at least its focus on intelligibility, is in service of another position, such as Kantian moral theory, and that that is the reason that perfectionism is not an alternative to such positions. As I read Cavell, however, I take it to be the other way around. Kantianism, utilitarianism, even virtue ethics, are, insofar as they are compatible, in the service of the perfectionist struggle for intelligibility. Moreover, the scope of perfectionism is greater than any single moral theory since, according to Cavell, perfectionism is "the province not of those who oppose justice and benevolent calculation, but of those who feel left out of their sway, who feel that most people have been left, or leave themselves out, of their sway." 2

Let me start with The Claim of Reason, and how Cavell rethinks the categorical imperative, to expand on what I mean by turning upside down Guyer's assumption that perfectionism's focus on intelligibility is in service of other moral aims. In his critique of John Rawls's analysis of morality as a form of reasoning within rule-governed practices such as games, Cavell suggests that there are "actions which are for us categorically imperative." ${ }^{3}$ The action, the thought, the word, becomes an expression of "your will." But it is not enough to say that our thoughts, words, and actions are self-imposed. If an action, word, or thought is categorically imperative, we have to take responsibility for it. We are answerable for them, as Cavell puts it (Claim of Reason, 312); that is, for knowing what I am doing, saying, and thinking, and perhaps also for what I am feeling. To Cavell, this means to be able to "elaborate the action: say why you are doing it, if that is competently asked; or excuse or justify it if that becomes necessary" (ibid., 311). Cavell talks about such elaborations as determining and taking a position (ibid., 
$268,312)$. Moral inquiries, or the struggle for intelligibility, becomes a form of navigation, of finding my position, where I stand. Hence, according to Cavell, moral discourse and moral rationality lay in "the methods which lead to a knowledge of our own position" (ibid., 312). Following Cavell's later work, I have talked about this as a matter of taking a stance. ${ }^{4}$ Taking a stance is, in Cavell, expressing knowledge and a perpetually preliminary definition of our selves. So here we have the first part of what it means to make oneself intelligible. It is a matter of clarifying, for others and yourself, your own moral position, your ethical posture.

Putting an ethical position at the center of moral thinking means that moral conversation is the ground where moral work takes place. The goal of such conversation is not an objectively or even intersubjectively grounded agreement. Rather, moral conversation involves confrontation of your own position with that of others, which does not mean reaching agreement. As Cavell puts it, "What is required in confronting another person is not your liking him or her but your being willing, from whatever cause, to take his or her position into account, and bear the consequences" (Claim of Reason, 326). Disagreements are not a sign of the irrationality of morality but of its rationality. In moral conversations or confrontations, you put your position at stake. In moral perfectionism, the disagreement and the sense of being lost in facing the other drive moral investigations and positioning. It is significant how Cavell summarizes this point in his memoirs: "In disputes about moral questions, standing is part of the dispute; a successful outcome is not necessarily agreement but a clarifying of positions and receiving respect for them" (Little Did I Know, 445-46).

I am not sure to what extent this diverts from some of the ambitions of Kant's moral philosophy. When Cavell says that there are actions that are for us categorically imperative, I understand him to mean that such actions can reveal our moral standing to ourselves and others, that our actions are our choice, that they reveal our will. But this rethinking of the imperative focuses less on respect for moral law as derived from our will in the Kantian sense and more on respect for others' positions.

Now let me explain how this forms a background for how I understand Cavell's as well as Kant's perfectionism as being concerned with making oneself intelligible, by turning to the quote from Cavell that Guyer uses in his essay:

What I characterized as making oneself intelligible is the interpretation moral perfectionism gives to the idea of moral reasoning, the demand for providing reasons for one's conduct, for the justification of one's life. ... Perfectionism proposes confrontation and conversation as the means of determining whether we can live together, accept one another into the aspirations of our lives. (Cities of Words, 25) 
Cavell does not talk about what one's conduct or life is aiming at, which Guyer seems to think is presupposed in perfectionism. Guyer claims that "to understand our actions and to justify them whether to ourselves or others, we have to understand what they are aimed at" ("Examples of Perfectionism," 7). He takes this to be the reason that Cavell adds that moral perfectionism is not an "alternative to other famous positions" (Cities of Words, 24-25). As I read Cavell, however, perfectionism is not primarily a matter of making my actions intelligible by explaining or clarifying their aim. Rather, moral intelligibility, in Cavell, is a matter of articulating my position, where I stand; it is to make myself intelligible, not only my actions. The perfectionist striving for intelligibility is not limited to an understanding of intentional actions but a striving for me to articulate my desires, wishes, drives, reasons, motives, and the conventions that I follow and those I am not following, both as these are clear to me and when they are obscured. Perfectionism means striving for intelligibility when I am lost in the weave of life with others and myself. Perfectionism explores how I, taking a position, can live with the other responsibly and with the position the other takes, even when it is in disagreement with my own.

Making my actions intelligible is simply one aspect of making myself intelligible. If "traditional" moral theories' aim is the justification of my actions or the aims of my actions or the maxims or norms of these actions, they are in the service of the perfectionist venture of making ourselves intelligible. So Cavell's perfectionism is not an alternative to Kantian moral philosophy because, to Cavell, as I read him, Kantian moral philosophy provides just one method for articulating ourselves. This means that Cavell can read Kant and return to Kant's works to assist him in suggesting ways in which we can try to make ourselves intelligible and clarify where we stand. This takes me into the next theme of my conversation with Guyer's text.

\section{Perfectionism and Philosophical Approaches to Texts}

To Cavell, perfectionism is a view of how thinking, philosophical and otherwise, develops or is perfected through such conversations throughout the history of thinking (Conditions Handsome and Unhandsome, 4-5). I take Cavell's expression of this aspect of moral perfectionism to be a continuation of his earlier suggestion in The Claim of Reason (3) that philosophy can be seen as a set of texts rather than a set of problems. I have already alluded to one feature of this view of philosophy. Confrontation and conversation with philosophical texts such as Kant's, like confrontation with others, can be a way for me to articulate my own moral position, both because it may help me adopt a posture and make it clear and also because it may provide me 
with opposition to my position. Reading philosophical texts and perfectionist readings of texts becomes a way to orient myself. I may not know where I stand until I find words to express that position or find out which words do not.

The way Guyer orients himself, by letting Kant's and Cavell's texts shed light on each other, can be read as a demonstration of such positioning. Guyer emphasizes the role of examples found in literature, stories, historical biographies, and film as reminders of our successful and destructive uses of freedom ("Examples of Perfectionism," 24). Moreover, Guyer recognizes that the films Cavell turns to, like his readings of Shakespeare and much other literature, demonstrate the protagonists' perfectionist struggles for intelligibility (ibid., 20-21). However, I want to accentuate what seems to me to be demonstrated only implicitly in Guyer's text: Cavell's reading of philosophical texts, literature, film, and music is itself a form of positioning. Emphasizing the importance of perfectionist conversations with texts might clarify not only what it means for Cavell to turn to film and literature but also his relation to Kant and other important historical figures in philosophy. Let me explain.

From his beginnings in the ordinary language philosophy of Austin and Wittgenstein to his recently published autobiography, the question of a text's representativeness has been at the heart of Cavell's philosophy. Ordinary language philosophy, as understood and practiced by Cavell, involves the reader in asking whether the claim of the philosopher to say "We say . .." can represent the reader, that is, whether the reader may be implicated in that "we." 5 The ordinary language philosopher asks whether his or her claims are claims to a community in which he or she can say "We say ..." or whether that conviction becomes isolating, as if the text represents no one (Cavell, Claim of Reason, 20). Cavell sometimes describes this as a test, a testing of whom I can take as my representative and a test of my own representativeness, as he does in Must We Mean What We Say? (95) and Little Did I Know (6-7). This doubled testing characterizes a form of conversation with texts.

As Cavell reads Emerson, this representativeness is expressed in perfectionist terms of transfiguration and conversion, which invokes certain ideas of both Plato and Kant. Guyer is right to point out that Cavell shares Kant's emphasis on the moral demand for human freedom and autonomy. "Transfiguration" and "conversion" invoke an image of losing our bonds, the bonds of the chained persons in Plato's cave, the bonds of our own nature in Kant, or the bonds of conformity in Emerson. In philosophy, in the history of philosophy represented in those texts we call "philosophical," perfectionism becomes a constant reworking of its own terms. Cavell reads Emerson's texts as an attempt to transfigure Kantian and Platonic terms in an effort to rework (amend) his own and his nation's constitution. Such amending 
or converting involves ordinary language philosophy's testing our representativeness of each other, as a nation or a community, but it also involves making a stand for what constitutes our selves. In a sense, it is a form of conversion of us as free from the chains of conformity by transforming the words we inherit from philosophy, from our community, into our words (Conditions Handsome and Unhandsome, 10-11). So what I take to be a conversation with philosophical texts in Cavell is also a way to render ourselves intelligible by using the terms of the text, not by letting them determine what I can say, but by converting them to become my terms. Involving myself in such a conversation with philosophy can thus be seen as starting on a perfectionist journey without a set end.

Accordingly, I understand Cavell to be saying that an ever-changing canon of philosophical texts, the canon I choose for myself, can exemplify a perfectionist journey, a continual transformation of terms and striving for intelligibility; but I do not turn to a specific text or work of art only for an example of moral exemplarity or moral symbolism, as perhaps Kant would suggest in considering the role of art for moral edification or the role of stories as moral examples. My turn to a particular text is rather a matter of finding a further form of perfectionist conversation with new words or where I relearn old ones, through which to render myself intelligible. My conversation with philosophical texts does not mean that I let the text itself become the means for me to render myself intelligible, but that it helps me toward a freedom by inviting me to transform and rework its terms.

I have spoken about philosophical texts so far, but Cavell's work shows that it is not only conversations with philosophical texts that produce perfectionist philosophy but also films, poetry, literature, opera, and so on. For instance, the films and plays Cavell reads in Cities of Words provide more than examples. Guyer makes clear how powerful the examples of perfectionism are that we find in Cavell's readings of film, theatre, and literature, and, admittedly, Cavell does at times talk of his reading of films as providing examples of moral issues. ${ }^{6}$ Nonetheless, Cavell's readings of films do not only bring out examples of perfectionism; the readings themselves are perfectionist conversations just as Cavell's readings of Emerson, Wittgenstein, and Austin are. These are conversations where I find myself lost, where my culture's criteria do not give me a satisfying way to go on. As I read Cavell, these conversations, these readings, philosophically sustain his own perfectionist search for intelligibility; likewise, reading Cavell can itself be part of our perfectionist journey.

In the very first pages of the introduction of Cities of Words, the text of Cavell's that Guyer mainly turns to, Cavell shows how his conversation with both philosophical and other texts transforms and enlarges a particular philosophical picture. Cavell opens the conversation as if between Emerson and Kant. He suggests that Emerson's saying "I know that the world I 
converse with in the cities and in the farms, is not the world that I think"7 is a different register of Kant's sense that the human being exists in two worlds-the world of sense, of objects and causality, and an intelligible world, of freedom and moral law. Cavell reads the "thinkers and artists" he discusses in the book as responding to such "insight of a split in the human self, of human nature as divided or double" (Cities of Words, 1). To mention just a few of the texts Cavell engages with: he takes Emerson to transfigure Kant's metaphysical division into an empirical division; Locke to maintain a division between a world of nature ruled by power and a political world ruled by human consent; Ibsen's play A Doll House to tell of a split between a present incomprehensibly unjust world and "a world of freedom and reciprocity which is almost unthinkable"; and Shakespeare's play The Winter's Tale to enact an image of a dreamed actual world where we are given arbitrary roles and a world where we do not need such roles but are free to play and dance (ibid., 1-2). In a sense, then, reading Cavell we follow his conversion of his words in conversation with these texts, just as he reads Kant, for example, as transforming Plato's particular image of the split of the human self. I take the conversions of the image of the split human self as demonstrating how the writing of philosophical texts (at least those with perfectionist ambitions), the rendering of oneself intelligible and free, can involve conversing with a range of different sources. The variety of different texts Cavell converses with and puts in conversation with each other provides a variety of approaches to converting the image of the divided self and to making the image my constitution.

Cavell turns to these texts for different registers of moral thinking (Cities of Words, 5). In a remark on what he finds in the romantic poetry of Coleridge and Wordsworth, he says he reads them "not for illustrations, but for allegories, experiments, conceptual investigations, a working out of this complex of issues, and I claim that that is what they are, that's what produces these texts." ${ }^{18}$ Later in the same discussion, Cavell says, "I want story-telling to be thinking" ("In Quest of the Ordinary," 238). It seems clear that the turn to extraphilosophical material is not a turn from philosophy but a turn to philosophy, to thinking. Cavell needs a variety of texts to think through what a split self, or other issues, may involve. He philosophizes by responding to texts, by thinking through (as) reading.

A perfectionist response to texts (philosophical texts, literature, film, art, and possibly also music) is a way to articulate the world of understanding without succumbing to tendencies to articulate such a world solely in terms of moral concepts or moral action. To Cavell, the perfectionism of the text, as Guyer argues, can be seen as a striving for freedom. This is not primarily a freedom to act, although it may involve that too, but a freedom to become and to render one's self and one's community intelligible. I take Cavell's approach to philosophy, his turn to the philosophers as well as to the literature and the films he reads, as a search for and an establishment of such jour- 
neys of the self where he, as a reader of philosophy, not only finds examples of philosophical texts that illustrate such perfectionist transformation but also where the reading (and the writing of such readings) is part of his own transformation and striving for intelligibility. Philosophy, reading philosophy, is itself a way of constructing a self beyond my self, a community beyond my community or, as Cavell does, a way of taking on Kant's idea of the human to think of herself as living in two worlds. Reading philosophy gives us access to a further world, to the world of intelligibility. This means taking philosophy to be a special form of education, training, and instruction.

\section{Perfectionism and Philosophy as a Form of Education of Grown-ups and Children}

Guyer, like many other readers of Cavell, refers to Cavell's saying that philosophy is a form of education for grown-ups and takes this to suggest that the explicit turn to education in Cavell is focused on adulthood. ${ }^{9}$ Of course, there are good reasons to read Cavell this way. The instruction Cavell finds in the couples in remarriage comedies, or the lack of instruction between the couple in Ibsen's A Doll House, or the instruction of ordinary language philosophers like Austin and Wittgenstein, are all instances of education for grown-ups. Undoubtedly, Cavell's idea of philosophy as education for grown-ups is an important concept in his philosophy, one that he does return to repeatedly. ${ }^{10}$ Also, as Guyer claims, Kant's attention to education (in "Lectures on Pedagogy," for example) is primarily focused on the moral education of children. ${ }^{11}$

My reconsideration of moral perfectionism's striving for intelligibility and of texts in the history of philosophy and elsewhere forms a basis from which one can reconsider how Cavell's educational thinking is focused on the education of adults and Kant's focused on children's education. I claim that the perfectionist striving for intelligibility, through positioning oneself within practices and within a language, requires one to work on one's words to become one's own, through conversations with texts and art as much as in conversation with others. This is a work that both children and grown-ups are involved in, though perhaps sometimes in different ways; for children, in order to be born, or initiated, into language, while, for grown-ups, in order to be reborn, or converted. As I read them, the idea of philosophy as the education of grown-ups is as pronounced in Kant as the idea of the moral education of children is in Cavell. I take both forms of education to be crucial for seeing them both as expressions of moral perfectionism and for understanding the roles of education in perfectionism.

Let me begin to consider how Kant's philosophy can be seen as a form of education for grown-ups by giving an account of what Cavell means by his suggestion that philosophy is an education for adults. This phrase comes at a pivotal moment in Cavell's philosophy, and it is used first to make a point 
about philosophy, as part of a description of the role of scenes of instruction where "my reasons come to an end and I am thrown back upon myself" by a pupil's reaction to my instruction. Cavell notes a difference between Wittgenstein's famous examples of a pupil's dissonant reactions to writing down a series of numbers, where I can say "This is just what I do" and take myself as the foundation when my reasons come to an end; and a case when moral reasons run out, for instance when a child asks, "Why do we eat animals?" or "Why are some people poor and some rich?" "Why do I have to go to school?" or "Do you love black people as much as white people?" or "Who owns the land?" Then, the Wittgensteinian answer, "This is what I do," seems deeply unsatisfying (Cavell, Claim of Reason, 124-25). The child's questions turn us toward our own sense of reason, and we may have to reconsider our culture's criteria. This is how Cavell goes on:

Then I may feel that my foregone conclusions were never conclusions $I$ had arrived at, but were merely imbibed by me, merely conventional. I may blunt that realization through hypocrisy or cynicism or bullying. But I may take the occasion to throw myself back upon my culture, and ask why we do what we do, judge as we judge, how we arrived at these crossroads. (ibid., 125)

Cavell, as I read him, calls for a certain form of education. It is an education not of the child asking inconvenient questions but of me, as I run out of conventional reasons in my attempts to answer them. My education begins when I, facing the child's questions, bring my own "language and life into imagination" and confront my culture's criteria with my own words and life. This kind of confronting of my own culture and how it may form my thinking and living is something Cavell wants of philosophy and what he calls an education for grown-ups. It is a view that I take to be a description of Cavell's ordinary language philosophy, a working out of what I mean and may mean with my words. It is also a foregrounding of Cavell's moral perfectionism since, according to Cavell, confronting my own culture's criteria, requires a growth of grown-ups and philosophers, a turning of my natural reactions or, as Cavell puts it, conversion. It requires that I go over the cultural ground I stand on and consider to what extent it is mine (ibid.). This is the kind of provocation, or education, Cavell wants of the readings of texts, works of art and film. A perfectionist reader receives instruction from a text by letting the text confront his or her life and words with others' lives and words. In this sense, the rebirth Cavell calls for is a matter of rendering myself intelligible anew by positioning myself within or outside my culture.

How is this vision of philosophy present in Kant? At first glance, it seems to me that the kind of education of grown-ups that Cavell aims for in his philosophy is not a primary task for philosophy in Kant's view. Instead, Kant seems to argue that art and religion provide such education. Art or aesthetic 
experience, according to Kant, as Guyer reads him in "Examples of Perfectionism" (22), is a way for us to learn and relearn, not the content of morality but "our freedom to be moral." Again, I take this as a form of instruction in making ourselves intelligible. The aesthetic experience not only illustrates our moral freedom, what I am and what I can be, but is also a way to render myself free. Similarly, as Guyer also notes, religion can function as a form of moral learning and relearning. ${ }^{12}$ The figure of Christ, as a human being overcoming human frailties, is exemplary of freedom and moral living even at the cost of great suffering.

It seems, then, as if Kant chiefly looks for extraphilosophical materials, such as religion and art, for the education of grown-ups, for freedom and intelligibility, which Cavell wants to find in philosophy. Perhaps, then, it is not surprising that Cavell frequently uses religious language, such as "conversion," "redemption," or "rebirth," and aesthetic expressions such as film, literature, and music, in his philosophizing. Or that he talks about the questions asked by writers such as Augustine, Luther, Rousseau, and Thoreau, reformers not only of religions but also of our selves, as providing the instruction grown-ups may need to be reborn. ${ }^{13}$

Nevertheless, Kant's philosophical project can itself be seen as calling for the kind of redemptive conversion Cavell looks for. For example, in the prefaces of Religion, Kant describes the philosopher as a teacher of reason. ${ }^{14}$ Philosophy of religion is described as bringing freedom to expand as far as its sciences reach (Religion, 6:9). The philosopher of religion may borrow from religious texts for his or her own purposes, but she or he also brings something to religion (ibid., 6:10). I take this to describe Kant's attempt to present a view of religion free from dogmatism. As I read him, Kant writes on religion to set his readers free, to have them follow precepts of their own reasons rather than dogmas of religious authorities.

It seems to me that, in every philosophical issue Kant turns to, the aim is to, as he puts it, instill "courage to use your own understanding." 15 The philosophical task of establishing a priori principles appears to be a way to instruct his readers to think for themselves. I read him as establishing a way for him and his contemporaries to release themselves from the dogmatisms of their time by letting reason investigate its own conditions, rather than letting reason be determined by the prejudiced conventions of current practices-all with the aim of setting the human being free.

To Kant, if I understand his project, whether turning to issues of morality, politics, or nature, the philosophical education he seeks seems mainly to have been "on the basis of principles" for reason. ${ }^{16}$ I take this to mean that reason renders itself intelligible to itself by establishing principles for its own activities - that is, rational beings render themselves intelligible by establishing principles for their judgments of morality and nature. Therein lies our liberation. To Cavell, both in contrast and in the same spirit, philosophy's task 
of liberation is a matter of finding ways to express myself in language that is not mine to own. ${ }^{17}$

Herein lies a fundamental difference between Kant and Cavell. According to Kant, we render ourselves free by acknowledging the rational principles for our thinking. It is a way for us to take control of our lives. For instance, the establishing of the categorical imperative as "the supreme principle of morality" can be seen as a way to remind us of the conditions for our moral thinking and for my making it mine by giving it a rational, philosophical grounding that is mine. ${ }^{18}$ Kant's work, as I read it, is an attempt to instruct us, as "grown-ups" involved in practices of moral discourse, in how to establish grounds for our discourse. To Cavell, however, the philosophical education of grown-ups is not primarily a matter of establishing principles of reason; rather, I have to turn toward every word I use, to make every word my own, when I find that laws and principles do not apply, when I am lost in the conventions laid out by my culture and my reason. Making my words mine, or finding my voice, as Cavell sometimes puts it, is, thus, not limited to the establishment of principles. Principles for reason are too limited. To Cavell, the struggle for freedom goes on beyond principled reasoning by turning to every particular moment in thinking and in language, every utterance, every word, as a claim that it is mine. It would seem, then, that Cavellian moral perfectionism is an attempt to give a Kantian education for freedom by involving its readers in writing themselves out of captivity and in making their words their own by laying claim to every word and, thus, claiming reason. ${ }^{19}$ That seems to me to be the reason that Cavell, as I read him, takes the struggle for intelligibility not as a means to become free but as an expression of freedom (perhaps a freedom not entirely coinciding with Kant's notion of freedom). It is an acknowledgment that the words that are given to me are not mine, that I do not own them as yet, but that, as I find myself lost in the confrontation with my culture's criteria, I can make them mine if I can redeem them by taking responsibility for them, by reworking them, converting them as well as myself, to become an expression of my voice, of my reasons, so to speak. ${ }^{20}$

Now, what about the education of children in Cavell? There are many occasions where Cavell turns to issues concerning youth and childhood. Let me turn to one of these to demonstrate how Cavell's philosophy should not be seen only, and perhaps not even primarily, as a turn to the education of grown-ups. Very much like Kant and countless other philosophers, Cavell's perfectionism takes the education of the young to be pivotal for a sound political life. Nonetheless, in his emphasis on the role of the friend for "democratic existence," Cavell takes a rather original position:

But in Emerson [moral perfectionism] should, I would like to say, be taken as part of the training for democracy. Not the part that must 
internalize the principles of justice and practice the role of democratic citizen - that is clearly required. ... I understand the training and character and friendship Emerson requires for democracy as a preparation to withstand not its rigors but its failures, character to keep the democratic hope alive in the face of disappointment with it. (Conditions Handsome and Unhandsome, 56)

What Cavell asks for is an education of the young that prepares them for the disappointment in discovering the "distance of any actual society from justice." To Cavell, this disappointment with democratic societies means that "the human individual meant to be created and preserved by democracy is apt to be undone by it" (ibid., 57). Children are asked to give consent to a democratic community they inherit from their elders and are left rendering themselves intelligible with words that they inherit from their elders (Claim of Reason, 27-28). The compromises involved in giving consent may mean that I lose the possibility to render myself intelligible, that the words I use are not mine. That is how I understand Cavell's calls for training, an education, of the young that builds their character to keep the democratic hope alive: that is, a hope that I can render myself intelligible, that the just city gives me access to myself in its community and with the words I inherit (Conditions Handsome and Unhandsome, 57).

In a sense, Cavellian perfectionism's call for an education to build a character of hope for democracy, a hope that my community can become worthy of my consent as it transforms in my approach to it, is very much like my approach to Kant's philosophy as an education for grown-ups. It is an education that is meant to teach us, both children and adults, how to render ourselves free and intelligible as we live the lives of religion, science, morality, or politics in the established practices of the communities we inherit. It is an instruction for making principles and words, our reasons and our expressions, our own. To my mind, such an approach to Kant's philosophy as education for grown-ups means that we read his work, as Cavell suggests, as one of a set of perfectionist texts and as a perfectionist instruction. But it also seems to go the other way around. Cavell's perfectionist education for democracy involves a Kantian education for freedom where reason is turned on itself and liberates itself from its own demands by creating new demands: in Cavell's case, by relearning words as my words, in Kant's case, as constructing principles for reason.

\section{Conclusion}

In disagreement with Guyer I have suggested that the perfectionist goal of rendering ourselves intelligible does not presume some other aim. Rather, striving for intelligibility and rendering oneself free are inseparable. Both rendering oneself free and striving for intelligibility, in moral perfectionism, 
mean forming one's own moral position in one's own terms, which may mean that a perfectionist view of freedom is not exactly the Kantian view. I have also emphasized that perfectionism, as rendering oneself intelligible, finding words to express oneself, involves an approach to texts, or philosophical readings of texts, art, music, and so on. Moreover, I have sketched out how both Kant's and Cavell's philosophies can be considered as a form of education for adults and how Cavell's philosophy also involves an explicit understanding of the kind of perfectionist education of the young a democracy needs.

Though I have drawn out some differences between my understanding of Cavellian perfectionism and Guyer's presentation of it, I do end with a similar conclusion: that perhaps Cavell has underestimated how near his moral perfectionism is to Kant. To emphasize this, let me look at an instance in Cavell's texts on perfectionism where he distances himself from Kant.

"Kant found an essential place for perfection in his view of it at the end, as it were, of his theory, as an unreachable ideal relation to be striven for to the moral law; in Emerson, this place of the ideal occurs at the beginning of moral thinking, as a condition, let us say, of moral imagination, as a preparation or sign of moral life"(Cavell, Conditions Handsome and Unhandsome, 62).

At first glance, Cavell's observation seems correct. When Kant speaks of perfection, it seems to be as an end, something to strive for, impossible to reach. Cavell's own, say, Emersonian focus on intelligibility puts such an effort at the beginning where Kantian moral theory works as a tool to render ourselves free and intelligible given certain conditions and aims. Perfectionism's striving for intelligibility is taking a step into the world of sense.

However, this underestimates Kant's critical project itself as being a part of a larger perfectionist project or, as I have suggested, as part of a perfectionist education for freedom and intelligibility. As Cavell puts it just before he distances himself from Kantian moral theory, when he speaks of Wittgenstein and Heidegger as philosophers of the ordinary,

[I]t is utterly significant that in [Wittgenstein and Heidegger]—as in Emerson-what strikes their readers as a tone of continual moral urgency or religious or moral or artistic pathos is not expressed as a separate study to be called moral philosophy, or religious philosophy, or aesthetics. The moral of which-or the aesthetics of which-what they write is nothing else than these topics or places of philosophy, but is always nothing but philosophy itself. Nothing less, nothing separate, can lead us from or break us of, our shameful condition. Philosophy presents itself as a (an untaken) way of life. This is what perfectionists will find ways to say. (Conditions Handsome and Unhandsome, 61-62)

If, as I want to suggest, Kant's philosophy can be seen as an education of grown-ups in Cavell's sense and if Kant's text is taken seriously as part of 
a set of perfectionist texts and read that way, then we could find this moral urgency in Kant as much as in Cavell's philosophical heroes. Kantian divisions of philosophy into what we may want to call aesthetics, moral philosophy, logic, metaphysics, philosophy of science, and so on, may admittedly resist such a reading. But if we read his efforts in these different areas as first and foremost concerned with finding ways of making ourselves intelligible, then he can surely be read as a perfectionist trying to break out from our shameful condition by presenting untaken ways of life. But then again, we should begin reading Kant, as we perhaps more naturally approach Cavell, with such an aim in mind. I suggest, then, that what we can gain from reading Kant and Cavell together, just as Cavell reads Emerson through Kant, is not a better interpretation of them but a way of breaking free of our conditions by putting ourselves at stake in perfectionist reiteration, reforming our words into untaken ways of life.

\section{Notes}

1. Stanley Cavell, Conditions Handsome and Unhandsome: The Constitution of Emersonian Perfectionism (Chicago: Chicago University Press, 1990), 4-5. Further references to this work are cited in the text.

2. Stanley Cavell, Cities of Words: Pedagogical Letters on a Register of the Moral Life (Cambridge, MA: Belknap Press of Harvard University Press, 2004), 25. Further references to this work are cited in the text.

3. Stanley Cavell, The Claim of Reason: Wittgenstein, Skepticism, Morality, and Tragedy (Oxford: Oxford University Press, 1979), 309. Further references to this work are cited in the text.

4. See Stanley Cavell, Little Did I Know: Excerpts from Memory (Stanford, CA: Stanford University Press, 2010), 445-46. See also Victor Johansson, "Dissonant Voices: Philosophy, Children's Literature, and Perfectionist Education," PhD diss., Department of Education, Stockholm University, 2013, 296-300; and "Questions from the Rough Ground," unpublished manuscript. All further references to Cavell's Little Did I Know are cited in the text.

5. Stanley Cavell, Must We Mean What We Say?, 2d updated ed. (Cambridge: Cambridge University Press, 2002), 4-5, 14-16. All further references to this work are cited in the text.

6. See, for example, Cavell, Cities of Words, 9.

7. Ralph Waldo Emerson, "Experience," in Selected Writings of Ralph Waldo Emerson, ed. W. H. Gilman (London, Penguin Books, 1965), 374.

8. Stanley Cavell, "In Quest of the Ordinary: Texts of Recovery," in Romanticism and Contemporary Criticism, ed. Morris Eaves and Michael Fisher (Ithaca, NY: Cornell University Press, 1986), 229-30. This essay has also been published as chapter three in Cavell's In Quest of the Ordinary. However, the version I refer to here and from which this quote is taken contains a question and answer section, which is not contained in the version in Cavell's book. All further references to this work are cited in the text.

9. Cavell, The Claim of Reason, 125; Guyer, "Examples of Perfectionism," 5. For further discussion, see also Hilary Putnam, "Philosophy as the Education of Grownups: Stanley Cavell and Skepticism," in Reading Cavell, ed. Alice Crary and S. Shieh (London: Routledge, 2006), and Naoko Saito and Paul Standish, 
eds., Stanley Cavell and the Education of Grownups (New York: Fordham University Press, 2012).

10. See, for example, how Cavell summarizes his discussion of remarriage comedies in Philosophy the Day after Tomorrow (Cambridge, MA: Belknap Press of Harvard University Press, 2006), 121-22.

11. Immanuel Kant, "Lectures on Pedagogy," in Anthropology, History, and Education, ed. Günter Zöller and Robert B. Louden (Cambridge: Cambridge University Press, 2007), 437-85.

12. I say "religion" and not "Christianity," which is the specific religion Kant discusses, since I take Kant's discussion of religion, and specifically the figure of the Christ, to be applicable in other religious contexts as well. For example, the figure of Christ as a prototype of moral exemplarity seems to me to apply to Buddha Shakyamuni as much as to Jesus.

13. Cavell, The Claim of Reason, 125; Stanley Cavell, This New Yet Unapproachable America (Chicago: University of Chicago Press, 1988), 44.

14. Immanuel Kant, Religion within the Boundaries of Mere Reason [Religion], in Kant, Religion within the Boundaries of Mere Reason and Other Writings, ed. and trans. Allen W. Wood and George di Giovanni (Cambridge: Cambridge University Press, 1998), 6:12. All further references to this work are cited in the text.

15. Immanuel Kant, "An Answer to the Question: What Is Enlightenment?," in Practical Philosophy, trans. Mary J. Gregor (Cambridge: Cambridge University Press, 1996), 8:34.

16. Immanuel Kant, Critique of Pure Reason, ed. and trans. Paul Guyer and Allen W. Wood (Cambridge: Cambridge University Press, 1999), 100, A xii-xiii.

17. Stanley Cavell, Senses of Walden (Chicago: Chicago University Press, 1981), 64.

18. Immanuel Kant, Groundwork of the Metaphysics of Morals, trans. Mary Gregor (Cambridge: Cambridge University Press, 1997), 4:392.

19. See Cavell, Conditions Handsome and Unhandsome, 39; and, for a more detailed argument, Stanley Cavell, In Quest of the Ordinary: Lines of Skepticism and Romanticism (Chicago: University of Chicago Press, 1988), 27-49.

20. Stanley Cavell, Philosophical Passages: Wittgenstein, Emerson, Austin, Derrida (Oxford: Blackwell, 1995), 65. For a discussion along the same lines, see Edward T. Duffy, Secular Mysteries: Stanley Cavell and English Romanticism (New York: Bloomsbury, 2013), 53-64. 